\title{
Gated blood pool SPECT: a new clinical tool to detect cardiac dyssynchrony?
}

\author{
Leo H. B. Baur
}

Received: 1 April 2008/Accepted: 9 April 2008/Published online: 24 April 2008

(C) The Author(s) 2008

Cardiac dyssynchrony, which can be identified by marked delay of ventricular activation between septum and lateral wall or between right and left ventricular contraction has a negative influence on cardiac function and cardiac symptoms in patients with an impaired left ventricular function. Mechanical consequences of dyssynchrony include suboptimal ventricular filling, a reduction in left ventricular $\mathrm{dP} / \mathrm{dt}$, a more severe mitral regurgitation, and paradoxical septal wall motion [1]. Ventricular dyssynchrony has been associated with increased mortality in heart failure patients [2].

Frequently biventricular pacing can restore cardiac synchronization, improve cardiac function and decrease symptoms in patients with a left ventricular ejection fraction below 35\%, severe symptoms (NYHA class 3 and 4) and a QRS width more than $130 \mathrm{~ms}[3,4]$. A biventricular pacemaker can restore asynchronous contraction by electrically activating both ventricles in a synchronized manner. This may improve also general ventricular contraction and reduce the degree of mitral regurgitation [5]. In addition, it may improve quality of life, functional class and exercise capacity and reduce hospitalizations and all-cause mortality [6]. Unfortunately a significant number of patients do not respond to cardiac resynchronization therapy with a biventricular

L. H. B. Baur $(\bowtie)$

Department of Cardiology, Atrium Medical Centre Parkstad, Henri Dunantstreet 5, 6401 CX Heerlen, The Netherlands

e-mail: 1br01@atriummc.nl pacemaker. It has been shown, that electrocardiographic parameters and left ventricular dimensions alone are not sufficient to predict outcome of cardiac resynchronization therapy.

Today cardiac imaging has become the cornerstone for selection of patients for cardiac resynchronization therapy. Frequently echocardiography with tissue Doppler imaging and strain rate imaging is used quantify asynchrony and select patients for biventricular pacing $[7,8]$.

Unfortunately echocardiographic imaging and Doppler imaging is sub-optimal in some patients. In this issue of the International Journal of Cardiac Imaging, Nichols et al. show, that regional cardiac function can be quantitated with gated blood pool SPECT [9]. They showed, that in normals, the left and right ventricle contracted nearly synchronously, with a RV-LV apical phase difference of $-3 \pm 6 \% / R R$. In patients with congestive heart failure, left to right apical phase and apex-to-base contraction times were significantly delayed. Also most right ventricular regional measures for intra-ventricular timing were lengthened and all measures for dispersion and dyssynchrony were significantly greater for patients with congestive heart failure versus normal individuals. These data were highly reproducible. Although the authors did not give us any information about the width of the QRS complex in patients with left ventricular dysfunction, the method looks promising to determine left ventricular dyssynchrony and select patients for biventricular pacing. Further studies are 
needed to define cut-off values for proper selection of biventricular devices with nuclear imaging and determine regional cardiac function before and after implantation of a cardiac resynchronization device. Also more data have to gained to select patients for biventricular devices and avoid improper selection with nuclear imaging. Which technique, echocardiography or nuclear imaging, will be the most appropriate for a given patient has to be determined yet. However, the time is there for increasing efforts to decrease the number of non-responders of cardiac resynchronization. This because the number of patients needing this device is rapidly increasing and costs can be limited by improving selection of those patients, who really have benefit of cardiac resynchronization therapy.

Open Access This article is distributed under the terms of the Creative Commons Attribution Noncommercial License which permits any noncommercial use, distribution, and reproduction in any medium, provided the original author(s) and source are credited.

\section{References}

1. Grines CL, Bashore TM, Boudoulas H, Olson S, Shafer P, Wooley CF (1989) Functional abnormalities in isolated left bundle branch block: the effect of interventricular asynchrony. Circulation 79:845-853

2. Shamim W, Francis DP, Yousufuddin M et al (1999) Intraventricular conduction delay: a prognostic marker in chronic heart failure. Int J Cardiol 70:171-178

3. Gorcsan J III, Abraham T, Agler DA, Bax JJ, Derumeaux G, Grimm RA, Martin R, Steinberg JS, Sutton MS, Yu CM; American Society of Echocardiography Dyssynchrony
Writing Group (2008) Echocardiography for cardiac resynchronization therapy. J Am Soc Echocardiogr 21(3):191-213

4. Hunt SA, Abraham WT, Chin MH, Feldman AM, Francis GS, Ganiats TG, Jessup M, Konstam MA, Mancini DM, Michl K, Oates JA, Rahko PS, Silver MA, Stevenson LW, Yancy CW, Antman EM, Smith SC Jr, Adams CD, Anderson JL, Faxon DP, Fuster V, Halperin JL, Hiratzka LF, Jacobs AK, Nishimura R, Ornato JP, Page RL, Riegel B; American College of Cardiology; American Heart Association Task Force on Practice Guidelines; American College of Chest Physicians; International Society for Heart and Lung Transplantation; Heart Rhythm Society (2005) ACC/AHA 2005 Guideline Update for the Diagnosis and Management of Chronic Heart Failure in the Adult: a report of the American College of Cardiology/American Heart Association Task Force on Practice Guidelines (Writing Committee to Update the 2001 Guidelines for the Evaluation and Management of Heart Failure): developed in collaboration with the American College of Chest Physicians and the International Society for Heart and Lung Transplantation: endorsed by the Heart Rhythm Society Circulation 112(12):e154-e235

5. Toussaint JF, Lavergne T, Ollitraut J et al (2000) Biventricular pacing in severe heart failure patients reverses electromechanical dyssynchronization from apex to base. Pacing Clin Electrophysiol 23:1731-1734

6. Cleland JG, Daubert JC, Erdmann E et al (2005) The effect of cardiac resynchronization on morbidity and mortality in heart failure. N Engl J Med 352:1539-1549

7. Rouleau F, Merheb M, Geffroy S, Berthelot J, Chaleil D, Dupuis JM, Victor J, Geslin P (2004) Echocardiographic assessment of the interventricular delay of activation and correlation of the qrs width in dilated cardiomyopathy. Pacing Clin Electrophysiol 15:544-549

8. Breithardt O, Herbots L, Claus P, Sutherland GR (2005) Cardiac resynchronization therapy. In Sutherland GR, Hatle L, Claus P, D'hooge J, Bijnens BH (eds) Doppler myocardial imaging. Hasselt, Chap 12, pp 279-287

9. Nichols KJ, Van Tosh A, De Bondt P, Bergmann R, Palestro CJ, Reichek NR (2008) Normal limits of gated blood-pool SPECT count-based regional cardiac function parameters. Int J Card Imaging. doi:10.1007/s10554-008-9304-6 